\title{
Michael Addition in Reactive Extrusion: A facile sustainable route to developing phosphorus based flame retardant materials
}

Pietro Simonetti $^{\mathrm{a}}$, Rashid Nazir ${ }^{\mathrm{a}}$, Ali Gooneie ${ }^{\mathrm{a}}$, Sandro Lehner ${ }^{\mathrm{a}}$, Milijana Jovic ${ }^{\mathrm{a}}$, Khalifah A.

Salmeia $^{\mathrm{a}}$, Rudolf Hufenus ${ }^{\mathrm{a}}$, Alexandra Rippl ${ }^{\mathrm{b}}$, Jean-Pierre Kaiser ${ }^{\mathrm{b}}$, Cordula Hirsch ${ }^{\mathrm{b}}$, Bertran Rubi $^{\mathrm{c}}$, Sabyasachi Gaan ${ }^{\mathrm{a} *}$

${ }^{a}$ Advanced Fibers, Empa Swiss Federal Laboratories for Materials Science and Technology, Lerchenfeldstrasse 5, 9014 St. Gallen, Switzerland

${ }^{\mathrm{b}}$ Particles-Biology Interactions, Empa Swiss Federal Laboratories for Materials Science and Technology, Lerchenfeldstrasse 5, 9014 St. Gallen, Switzerland

${ }^{\mathrm{c}}$ Molecular and Biomolecular Analysis Service ETH Zurich, HCI E 323, Vladimir-PrelogWeg 1-5/10, 8093 Zürich, Switzerland

\section{*Corresponding Author}

Sabyasachi Gaan

sabyasachi.gaan@empa.ch

$+41587657611$

Key Words: phosphine oxide, reactive extrusion, flame retardancy, polyamide 6, Michael addition, in vitro toxicity assessment 


\section{Abstract}

This study addresses three very important aspects of sustainable development of new flame re-tardant material, i.e. in situ solvent free synthesis of flame retardant macromolecules during thermal processing of polymers, their leaching behavior from the polymer matrix and their preliminary toxicity assessment. Polyamide 6 (PA6) was functionalized by a novel reactive extrusion process. In situ synthesis of phosphine oxide based macromolecules was obtained via Michael addition reaction of divinyl phenyl phosphine oxide (DVPPO) and piperazine during the reactive extrusion process. The formation of phosphine oxide macromolecules (oligomers and low molecular weight polymers) were confirmed by NMR study of the modified PA6 polymer and UPLC-MS analysis of extracts from PA6 samples. Elemental analysis of the modified PA6 after the extraction with chloroform and water confirmed retention of majority of phosphorus species, confirming the beneficial effect of large macromolecular additives. This non-leaching behavior of modified PA6 is an important requirement for thin walled substrates like fibers and films where long-term durability is very important. The reactive extruded PA6 was successfully processed into textile fibers via melt spinning process in a laboratory spinning plant. The presence of phosphine oxide macromolecules in PA6 matrix had a lubricating effect, which has influence in the thermal processing and final properties of the fiber. The modified PA6 was evaluated for fire performance in small-scale fire tests where it showed improved fire performance. Moreover, the preliminary toxicity assessment of the relatively unknown DVPPO, via a well-established in vitro platform showed no adverse effects on cell viability. 
Graphical Abstract:

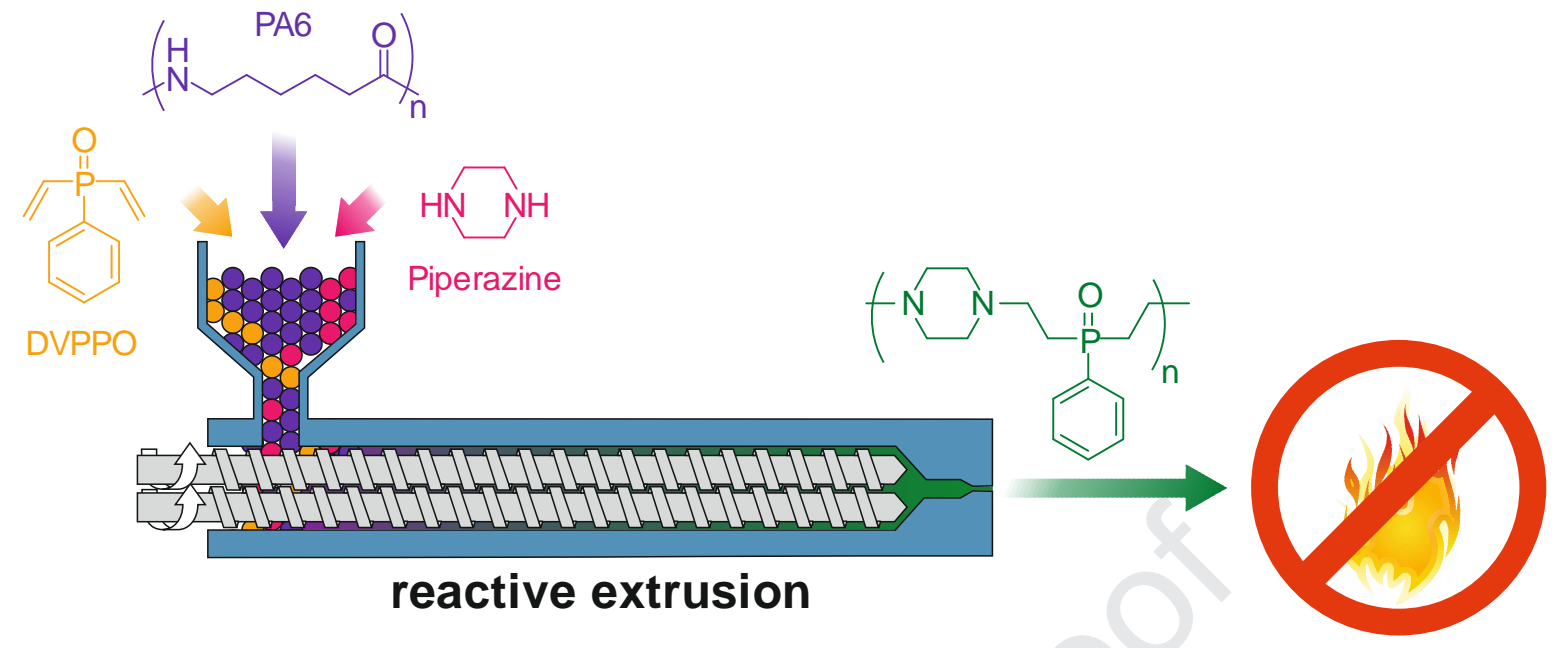




\section{Introduction}

Thermoplastic polymers are commonly flame retarded via addition of small additives in bulk during their processing. [1-3] Functionalizing polymers with additives is economical and offers great degree of flexibility in their production. In most cases small additives are physically blended into the polymer matrix and in some cases it may result in blooming during their processing [4] or they may leach out from final products and create environmental pollution.[5-8] Leaching of additives from polymers is a critical issue in case of thin walled products like films and fibers.[9] Textile fibers undergo harsh processing treatments such as dyeing and finishing where the fibers are exposed to elevated temperatures $\left(100{ }^{\circ} \mathrm{C}\right.$ and above) for extended period (60 $\mathrm{min})$ in aqueous environment.[10] In addition, textile products are exposed to severe laundry cycles (up to $60^{\circ} \mathrm{C}$ ) throughout their lifetime. Leaching of additives will not only create environmental issue but also reduce the functionality of the product.

Recent approaches to overcome some of these issues have been to develop high molecular weight or polymeric flame-retardants, which can be either used alone or blended with other polymers. [11-14] It is believed that such incorporation of hyperbranched [15] or polymeric [11] flame retardant prevents its migration from the polymer. Another way to prevent the additive from leaching out from the polymer is to react it to the polymer matrix. Reactive processing of flame retardant additives is quite common in thermosetting polymers $[16,17]$. Reactive processing of thermoplastic polymers is challenging due difficulty in controlling chemical reactions in solvent free medium however, it is a growing field of technology for developing sustainable polymers. [18] Reactive extrusion is considered a sustainable process as the reactions (i.e. polymerization or grafting of monomers) generally happen in molten state without the use of solvents. In addition, the reactive extrusion avoids the use of an extra solvent based synthetic step normally encountered in conventional additive synthesis, thus ensuring saving in energy and resources. 
Reactive extrusion is a common technique used to perform chemical reactions of polymer and/ or polymerizable monomers during their thermal processing. Free radical grafting of reactive monomers [19, 20], chain extension of polymers via reaction with epoxides [21] and ring opening polymerization of monomers are some of the common chemical approaches used in the reactive extrusion of polymers. The use of reactive extrusion technology to improve flame retardancy of polymers is relatively unknown. Reaction of melamine phosphate and pentaerythritol during the thermal processing of various polymers to improve their flame retardancy has been explored in some previous work.[22-24] Flame retardant modification of polylactide by incorporating inert fillers such as carbon nanotubes and combination of ammonium polyphosphate, melamine and organoclay during reactive extrusion of polylactide has also been performed. [25, 26] Recently a patent describing manufacturing of flame retardant polyolefin resins has been reported where polyolefin containing reactive groups like anhydrides, epoxies, carboxylic acids, ketones, and isocyanates were reacted with an amine containing flame retardant moiety in an extrusion barrel.[27]

Michael addition reaction is commonly used in organic synthesis[28] to synthesize bioactive natural products[29], to modify [30]and synthesize polymers[31]. The use of Michael addition reaction in modification of polymer during the extrusion process is not known in the literature. In Michael addition reaction the adducts react to form final product without any byproducts and thus it could be suitable reaction in reactive extrusion of polymers.

Toxicological aspects of new materials (i.e. flame retardant additives) play an important role to protect human safety as well as the environment. Assessing potential adverse effects of new materials already during the production process is thus indispensable as it ensures their sustainable development and production. In the past, eco-toxicological assessments according to Organization for Economic Co-operation and Development (OECD) guidelines [32, 33] have been performed. In combination with preliminary safety evaluations using a well-established 
in vitro platforms for cytotoxicity $[34,35]$ the successful commercialization of new phosphorus flame retardant additives became possible.[36]

In this work, we report a novel approach to modify PA6 to improve its flame retardancy and address the issues regarding small flame retardant additives. Michael addition reaction of unsaturated phosphine oxide moiety and an amine during the thermal processing of PA6 were performed to form in-situ phosphine oxide macromolecules. Divinyl phenyl phosphine oxide (DVPPO) was chosen as the unsaturated compound and piperazine was chosen as the nucleophile for this addition reaction. Chemical characterization of phosphine oxide macromolecules formed in situ via Michael addition reaction during the extrusion process was performed using NMR spectroscopy, UPLC-MS and MALDI-TOF. The rheology of the modified PA6 and its thermal behavior were also investigated. As a proof of concept, the modified PA6 polymer was further processed into fibers in a pilot spinning plant. The fire performance of PA6 samples was assessed using small-scale fire tests. Finally, the safety of the relatively unknown compound DVPPO, was analyzed using a well-established in vitro platform for acute cytotoxicity.

\section{Experimental Section}

Phenylphosphonic dichloride, 97\% was purchased from Acros Organics, Germany. All other chemicals for synthesis and reactive extrusion were purchased from Sigma Aldrich (Switzerland) and were used without further purification. Polyamide 6 (Grilon Natur A26) (17000 g/mol, 30-40 $\left.\mu \mathrm{g} / \mathrm{g}-\mathrm{NH}_{2}, 55-70 \mu \mathrm{g} / \mathrm{g}-\mathrm{COOH}\right)$ was provided by EMS-CHEMIE AG, Switzerland.

Synthesis of DVPPO

DVPPO was synthesized according to a modified literature procedure.[37] The details of synthesis procedure of DVPPO and its NMR characterization are presented in supplementary in- 
formation S1 and S2 respectively. ${ }^{1} \mathrm{H}$ NMR (400.2 MHz, HFIP-d $\left.\mathrm{d}_{2}\right) \delta(\mathrm{ppm})$ : 7.74-7.60 (m, 5H), 6.5-6.17 (m, 6H), ${ }^{31} \mathrm{P}$ NMR (162.0 MHz, HFIP-d $\left.\mathrm{d}_{2}\right) \delta(\mathrm{ppm})$ : 33.6. The thermal data of DVPPO is presented in supplementary information S3A and S3B.

\section{Polymer Processing}

\section{Kneading trials}

The first proof of concept of reactive extrusion of additives was performed by melt compounding in a laboratory internal mixer (HAAKE Rheomix 600, Thermo Fisher Scientific, Germany) equipped with Banbury type rotor design at $70 \mathrm{~g}$ scale. PA6 (Grilon A26, EMSChemie, with a density of $1.14 \mathrm{~g} / \mathrm{cm} 3$ ) was mixed with $5.1 \mathrm{wt} \%$ of DVPPO and $2.5 \mathrm{wt} \%$ of piperazine (corresponding to $1: 1$ molar ratio) for $15 \mathrm{~min}$ at $240{ }^{\circ} \mathrm{C}$ with a rotation speed of 30 $\mathrm{rpm}$. Prior to any thermal processing, PA6 was dried for $8 \mathrm{~h}$ at $80{ }^{\circ} \mathrm{C}$ under vacuum. The modified PA6 was removed from the internal mixer, cooled, and shredded into coarse granules, approximately 2-3 $\mathrm{mm}$ in diameter.

\section{Michael Addition Kinetic Studies}

0.5 gram of DVPPO + Piperazine (1:1 molar ratio) were taken in glass tube and heated to 100 ${ }^{\circ} \mathrm{C}$ at 30 bar nitrogen pressure for required duration of time in a microwave reactor (Synthwave from MLS GmbH). Similar experiments were also performed in pressure glass tube (Ace pressure tube, bushing type, back seal, volume $\sim 15 \mathrm{~mL}, \mathrm{~L} \times$ O.D. $10.2 \mathrm{~cm} \times 25.4$ $\mathrm{mm}$ ) in heating blocks on a hot plate. After each allotted reaction time, the reaction products was monitored by NMR spectroscopy.

\section{Extrusion trials}


For the large scale $(3 \mathrm{~kg}$ ) reactive extrusion trials, PA6, $5 \mathrm{wt} \%$ of DVPPO and $2.5 \mathrm{wt} \%$ of piperazine were physically mixed under nitrogen and fed to the extruder by a dosage system (under nitrogen and continuous cooling of the inlet to avoid additive premature melting and reaction). For this purpose, a twin-screw extruder was used (Dr. Collin GmbH, Germany, with a screw diameter of $16 \mathrm{~mm}$ and $\mathrm{L} / \mathrm{D}$ ratio of 36) with a temperature profile ranging from 250 to $265^{\circ} \mathrm{C}$ and a die temperature of $251^{\circ} \mathrm{C}$ (capillary die with diameter of $2 \mathrm{~mm}$ ). The extruder was operated at $110 \mathrm{rpm}$ with a constant throughput of $8 \mathrm{~g} / \mathrm{min}$. The PA6/ DVPPO/ Piperazine compound was then pelletized to $1-2 \mathrm{~mm}$ pellets.

\section{Melt spinning}

Fiber melt spinning was carried out on a customized pilot melt-spinning plant originally built by Fourné Polymertechnik (Germany). This plant - having features corresponding to an industrial plant - enables the production of multicomponent filaments with various fiber crosssections and material combinations with a throughput of $0.1-5 \mathrm{~kg} / \mathrm{h}$. For this study, PA6 pellets manufactured in the reactive extrusion process were melted in a single screw extruder (screw diameter of $14 \mathrm{~mm}$ and L/D ratio of 25) equipped with a melt pump (nominal throughput was $6 \mathrm{~cm}^{3} / \mathrm{min}$ ). Extruder temperatures were set between 250 and $275{ }^{\circ} \mathrm{C}$, and spin pack temperature was kept at $245{ }^{\circ} \mathrm{C}$. The draw ratio (ratio between the winder speed and that of the take-up godet) was 4.0, applying a final winding speed of $1600 \mathrm{~m} / \mathrm{min}$. Prior to the melt spinning process, the pellets were dried in a vacuum oven at $100{ }^{\circ} \mathrm{C}$ for 12 hours. The molten compound was spun through a circular monofilament die with an inner diameter of $0.5 \mathrm{~mm}$ and a capillary length to diameter ratio of $\mathrm{L} / \mathrm{D}=4$. Detailed information about the melt spinning equipment is described in a previous work. [38]

\section{Analytics}

\section{Rheology}


Rheological tests were carried out on an Anton Paar Physica 301 MCR rotational rheometer (Austria). All tests were performed at a constant temperature of $250{ }^{\circ} \mathrm{C}$ under nitrogen in a parallel plate fixture (plate diameter of $25 \mathrm{~mm}$ and gap of $1 \mathrm{~mm}$ ). PA6 samples were thermally processed into $(0.5 \mathrm{~mm}$ plates $)$ using a hot press at $250^{\circ} \mathrm{C}$. The plates were then dried in a vacuum oven overnight at $80{ }^{\circ} \mathrm{C}$ prior to the measurements. Before starting a measurement, the samples were relaxed for $60 \mathrm{~s}$ in the rheometer to minimize the deformation history. Afterwards, angular frequency sweep experiments were recorded at a constant strain of $1 \%$.

\section{Tensile Measurements}

The load-strain behavior of the PA6 fibers was evaluated using the Statimat ME+ tensile tester (Textechno H. Stein, Moenchengladbach, Germany) with $10 \mathrm{~N}$ load cell. A set of 20 single filament tests per fiber sample were performed with $50 \mathrm{~mm}$ test length at a constant rate of extension of $200 \mathrm{~mm} / \mathrm{min}$.

\section{Extraction experiments}

To estimate the leaching of phosphorus species, the PA6 samples were extracted with chloroform or water at room temperature $\left(30^{\circ} \mathrm{C}\right)$ or at $100{ }^{\circ} \mathrm{C}$ for required duration $(1 \mathrm{hr}$ and $16 \mathrm{hr})$ of time in a SynthWAVE Microwave reactor. In a typical experiment, $1 \mathrm{~g}$ of sample was placed in a test tube containing $10 \mathrm{ml}$ of extraction medium (chloroform or water) and heated to $100{ }^{\circ} \mathrm{C}$ for required duration at 30-bar nitrogen pressure. The polymer residue was separated from the extract by filtration and further analysis performed on the extract and the polymer. 
Phosphorus content analyses of samples was carried out using the inductively coupled plasma optical emission spectrometry method (ICP-OES), on an Optima 3000 (PerkinElmer AG, Rotkreuz, Switzerland) apparatus. Sample preparation for ICP-OES consisted of mixing 300 mg of sample with $1 \mathrm{~mL} \mathrm{H}_{2} \mathrm{O}_{2}$ and $3 \mathrm{~mL} \mathrm{HNO}_{3}$, followed by digestion using a microwave.

\section{Thermal Experiments}

Thermogravimetric analysis (TGA) of the PA 6 samples and DVPPO was carried out by using a NETZSCH TG209 F1 Iris instrument. The sample (exact weighing of approx. $3 \mathrm{mg}$ ) was heated from 25 to $800{ }^{\circ} \mathrm{C}$ at a heating rate of $10{ }^{\circ} \mathrm{C} / \mathrm{min}$. The measurements were performed two times under a nitrogen and air atmosphere with a total gas flow of $50 \mathrm{~mL} / \mathrm{min}$.

The melting point of PA6 samples and DVPPO were analyzed using a NETZSCH DSC Polyma 214. Samples (ca. 2-3 mg) in closed crucibles were heated to $300{ }^{\circ} \mathrm{C}$ at a heating rate of $10^{\circ} \mathrm{C} / \mathrm{min}$.

A direct insertion probe mass spectrometry (DIP-MS) analysis was performed for a 1-2 $\mu \mathrm{g}$ sample using ThermoQuest FINNIGAN apparatus (Austin, TX, USA). The probe was heated from $30{ }^{\circ} \mathrm{C}$ to $450{ }^{\circ} \mathrm{C}$ at a rate of $50 \mathrm{~K} / \mathrm{min}$ and $10^{-6}$ mbar pressure.

\section{Gel Permeation Chromatography}

Gel Permeation Chromatography (GPC) analyses were performed by dissolving pieces of PA6 fibers and passing the solution through a Viscotek GPC max VE 2001 solvent/sample module equipped with Viscotek TriSEC Model 302 detector unit. Measurements were made on a PSS PFG (7 $\mu \mathrm{m}$ particle size) 3-column set( 100, 1000 and 4000 $\AA$ respectively) and the measurement conditions were: column temperature of $35^{\circ} \mathrm{C}, 1 \mathrm{ml} /$ min hexafluoroisopropanol (HFIP) containing $20 \mathrm{mmol}$ of sodium trifluoroacetate as the sol- 
vent, injection volume of $100 \mu$ 1. 2-4 mg of polymer sample was dissolved in $1 \mathrm{ml}$ of HFIP and stirred for a 6 hours before injection in GPC.

Ultra performance liquid chromatography-Mass spectrometry (UPLC-MS)

Extracts from PA6 samples were isolated and dissolved in acetonitrile, filtered and injected in Waters Aquity H-Class UPLC system (C18 column, $1.7 \mathrm{um}, 2.1$ x $50 \mathrm{~mm}$ ) at $40{ }^{\circ} \mathrm{C}$ (run time $5 \mathrm{~min}$, flow $0.5 \mathrm{ml} / \mathrm{min}$ ) with a gradient method (at $0 \min 95 \%$ water, $5 \%$ acetonitrile at 3 $\min 20 \%$ water, $80 \%$ acetonitrile, at $3.1 \min 95 \%$ water, $5 \%$ acetonitrile, at $5 \min 95 \%$ water, $5 \%$ acetonitrile). The eluent was analyzed with MS (Qda from Waters), in ESI+ mode, cone voltage $20 \mathrm{~V}$ with a mass range of $80-1250 \mathrm{~m} / \mathrm{z}$.

Matrix-assisted laser desorption/ionization - time of flight MS (MALDI-TOF)

The product of the solid-solid-reaction in the microwave was powdered and then mix with the matrix (2,5-dihydroxybenzoic acid) 1:10. It was then analyzed with a Bruker UltraFlex II MALDI-TOF-MS in positive mode with a mass range of $200-20100 \mathrm{~m} / \mathrm{z}$.

\section{Small-scale Fire tests}

Limiting Oxygen Index (LOI) values of all films were measured on FTT oxygen index apparatus according to ASTM D2863-97. The dimension of specimens for LOI test was $150 \times 50$ $\times 0.5 \mathrm{~mm}$. Vertical burning tests were performed according to the Swiss Standard (BKZ-VB) as described in the literature.[39] Polyamide plates were exposed to a flame (45 $)$ for 15 seconds in a vertical orientation and the burn length and burn time recorded. Five specimens were tested for LOI and vertical burning tests and an average value reported. 


\section{In vitro toxicity assessment of DVPPO}

The in vitro toxicity assessment of DVPPO was carried out as described before for other flame retardant additives [34] and is only briefly summarized here.

\section{DVPPO solution}

DVPPO was solubilized in pure dimethylsulfoxid (DMSO) at a concentration of $500 \mathrm{mM}$, serially pre-diluted in DMSO and applied to cells in complete cell culture medium (MTS assay) or Hanks balanced salt solution (HBSS; DCF assay).

\section{Cell culture conditions}

The human alveolar epithelial cell line A549 (ATCC: CCL185) as well as the human monocytic cell line THP-1 (ATCC: TIB-202) were cultured in Roswell Park Memorial Institute (RPMI-1640) medium (Sigma-Aldrich) supplemented with 10\% FCS (Fetal Calf Serum; Lonza), $0.2 \mathrm{mM}$ L-glutamine (Gibco) and $1 \mathrm{x}$ penicillin, streptomycin, neomycin (PSN) (Gibco) at $37{ }^{\circ} \mathrm{C}$ in humidified atmosphere containing $5 \% \mathrm{CO}_{2}$ (hereafter referred to as complete cell culture medium and standard growth conditions, respectively). A549 cells were subcultured at $80-90 \%$ confluency using $0.5 \%$ trypsin-EDTA (Sigma-Aldrich). Medium was replaced in THP-1 suspension cultures when the cell density reached $8 \times 10^{5}$ cells $/ \mathrm{mL}$. Before experimental start, THP-1 monocytes were allowed to differentiate into macrophages for $72 \mathrm{~h}$ in the presence of $200 \mathrm{nM}$ phorbol-12-myristate-13-acetate (PMA; Sigma-Aldrich). All experiments in this study were carried out with differentiated THP-1 macrophages.

\section{Cell viability assessment (MTS assay)}

Cell viability was assessed using the CellTiter96®-AQueous One Solution (Promega) containing MTS (3-(4,5-dimethylthiazol-2-yl)-5-(3-carboxymethoxy-phenyl)-2-(4-sulfophenyl)$2 \mathrm{H})$ as a water-soluble tetrazolium compound according to the manufacturer's protocol. The 
assay was performed in 96-well cell culture plates with $1 \times 10^{4}$ A549 cells or $8 \times 10^{4} \mathrm{THP}-1$ cells seeded $24 \mathrm{~h}$ or $72 \mathrm{~h}$ prior treatment, respectively. $\mathrm{CdSO}_{4}$ served as the positive control agent and absorption was measured at $490 \mathrm{~nm}$ using a Multimode plate reader (Mithras ${ }^{2}$, Berthold Technologies).

\section{Detection of reactive oxygen species (ROS) (DCF assay)}

ROS was detected with the 2',7'-dichlorodihydrofluorescein diacetate $\left(\mathrm{H}_{2} \mathrm{DCF}-\mathrm{DA}\right.$; Molecular Probes) assay as described in detail elsewhere.[40] The assay was performed in 96-well cell culture plates with $2 \times 10^{4}$ A549 cells or $8 \times 10^{4}$ THP- 1 cells seeded 24 h or 72 h prior treatment, respectively. Cells were loaded with $\mathrm{H}_{2}$ DCF-DA (50 $\mu \mathrm{M}$ in HBSS) for $1 \mathrm{~h}$ and subsequently treated for $2 \mathrm{~h}$ with increasing concentrations of DVPPO in HBSS. The peroxynitritegenerating compound 3-morpholinosydnonimine (Sin-1; $50 \mu \mathrm{M}$ in HBSS) served as the positive control. Fluorescence intensity was measured using a Multimode plate reader (Mithras ${ }^{2}$, Berthold Technologies) at an excitation wavelength of $485 \mathrm{~nm}$ and an emission wavelength of $528 \mathrm{~nm}$.

\section{Data processing}

Blank samples that did not contain cells but were treated exactly the same way were run with each cell-based assay. Values given in the graphs are blank-corrected and subsequently normalized to the untreated control sample. The mean and corresponding standard deviations of at least three independent experiments are given. For each experiment, three technical replicates were carried out.

\section{Results and Discussion}


The goal of this work was to develop flame retardant PA6 where the flame retardant moiety does not leach out from the polymer during subsequent processing or usage. As small molecule additives generally leach out, we planned to incorporate flame retardant macromolecules in PA6. It was logical to choose phosphorus moiety as a building block to flame retardant PA6 as it has versatile flame retardant behavior and has been proven efficient in flame retardation of PA6. [2, 3] As PA6 is processed at high temperature, a suitable additive needs to be compatible with the processing temperature $\left(\sim 250{ }^{\circ} \mathrm{C}\right)$. We chose DVPPO as a phosphorus moiety as it has two vinyl groups, which can react with diamines via Michael addition reaction to produce linear macromolecules. Additionally DVPPO has P-C bonds which make the $\mathrm{P}=\mathrm{O}$ group stable to nucleophilic attack from functional groups $\left(-\mathrm{NH}_{2}\right.$ and $\left.-\mathrm{COOH}\right)$ of polyamides. In this work, piperazine was chosen as a nucleophile for the Michael addition reaction. It is a cyclic secondary amine and avoids any possible cyclisation reactions during Michael addition reaction, typical of primary amines.[41] The TGA data of DVPPO and piperazine (supplementary information S3A) show mass loss below the processing temperature of the PA6 $\left(\sim 250^{\circ} \mathrm{C}\right)$. In fact, the DIP-MS analysis (supplementary information S4A) show that both DVPPO and piperazine volatilize without decomposing at temperatures below $250{ }^{\circ} \mathrm{C}$. As extruders are closed systems, they work under pressure and thus volatilization of such additives is prevented. Reactive extrusion of volatile additives is a common practice in polymer processing[42].

The envisioned Michael addition reaction of DVPPO and piperazine is shown in Scheme1. A wide variety of linear and crosslinked macromolecules for biomedical application has been developed using Michael addition reaction.[31] The use of this reaction in reactive extrusion of polymers is unknown. As it is an addition type reaction, no byproducts are generally produced and thus maybe very suitable for reactive extrusion process. Additionally, the functional groups in polyamides are compatible with components needed for Michael addition $(\alpha, \beta$ unsaturated compound and a nucleophile) reaction. Polyamides contain amino end groups, 
and they can potentially react with the $\alpha, \beta$-unsaturated compound however such reactions can be considered minor due to limited amount of amino group in the polymer $(\sim 0.06 \mathrm{~mol} / \mathrm{kg})$ used in our experiment.

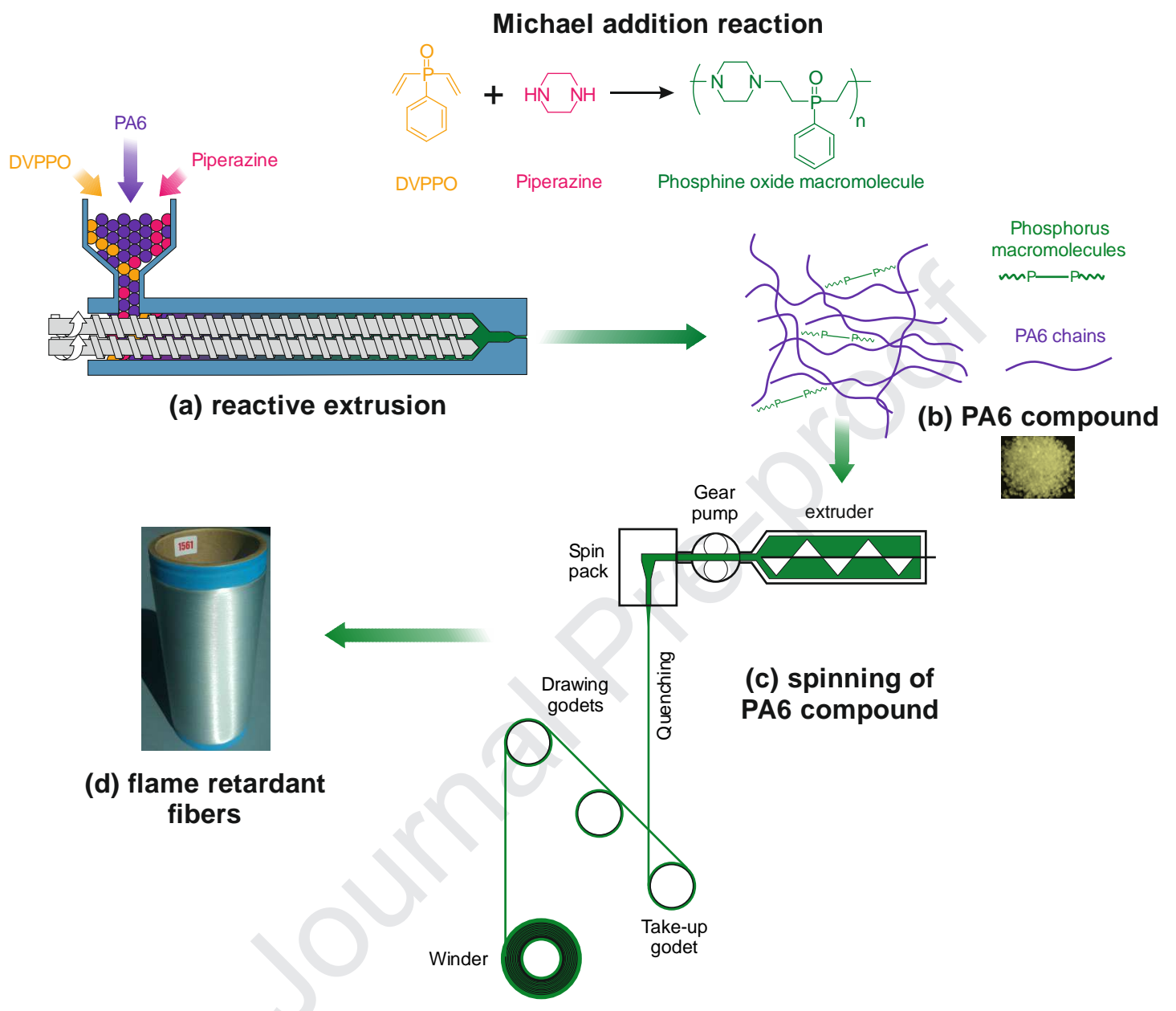

Scheme 1: Reactive extrusion of PA6 and its processing

\section{Preliminary screening in kneading experiments}

The feasibility of Michael addition reaction of DVPPO and piperazine during the melt processing of PA6 was tested by preliminary kneading experiment. Required amount of DVPPO and piperazine (1:1 molar ratio) was melt processed in kneader for 15 mins at $240{ }^{\circ} \mathrm{C}$. These processing conditions are typical for melt processing of polyamides during masterbatch or compound manufacturing. The required concentration of DVPPO was chosen to obtain a phosphorus content of $\sim 0.8 \mathrm{wt} \%$ in the polymer. Such phosphorus concentrations are typical 
for flame retardant polyamide fibers.[43] The initial kneading trials were promising as no processing problems (crosslinking) were observed. The crosslinking reaction could arise from the self-polymerization of DVPPO at elevated temperatures. It is known in the literature that vinyl groups connected to phosphorus species are not very reactive in radical polymerization process. [44] Crosslinking arising from homo-polymerization and grafting of DVPPO, which would have resulted in an increase of the torque, did not occur. On the contrary, the torque dropped considerably when the additives were filled in, indicating that the additives act as lubricants under the processing condition. The kneaded material turned yellowish during mixing, suggesting oxidation of the polymer. This may be due to open conditions (access to oxygen) existing in typical kneading experimental setups which leads to possible oxidative decomposition of polyamide.

To confirm that the Michael addition reaction of DVPPO and piperazine leads to in situ formation of phosphine oxide based macromolecules during the kneading trials, we analyzed the P content (wt.\%) of the modified PA6. It is expected that phosphine oxide based macromolecules will get trapped due to entanglement in the PA6 during their processing and cannot be extracted from the polymer. The modified PA6 obtained from the kneading trials was crushed into powder and extracted with chloroform at $100{ }^{\circ} \mathrm{C}$ in a microwave reactor under pressure. The P content (wt.\%) of the modified PA6 before and after extraction is summarized in Table 1. The P content (wt.\%), actual value $(0.74 \%)$ is slightly lower than the theoretical value $(0.82 \%)$ which may be due to loss of additive during feeding into the kneader. DVPPO has a low melting point $\sim 47^{\circ} \mathrm{C}$, which makes it stick to glassware and hot metal surfaces. The results show that the majority of phosphorus $(\sim 58 \%)$ is retained in the PA6 after the extraction process. DVPPO and piperazine is freely soluble in chloroform and thus any unreacted species can easily be removed during the extraction procedure. As majority of phosphorus remains in the polymer after the extraction process, it is likely that phosphine oxide based mac- 
romolecules are formed during the reactive extrusion process. Though it is believed that the majority of phosphorus retention in the PA6 after reactive extrusion is because of DVPPO reacting with piperazine to form phosphine oxide moieties, other minor side reactions of DVPPO can also lead to phosphorus retention in PA6. Polyamide 6 has amino end groups and it is likely that some DVPPO can react via Michael addition with the primary amino end groups to form cyclic products[45]. In addition, other minor radical reactions of DVPPO such as homopolymerization and grafting to the PA6 chains can also occur. To prove the possibility of such reactions, kneading trial of PA6 with DVPPO alone was also performed. We observed some phosphorus retention $(\sim 20 \%)$ in the modified PA6 after chloroform extraction. It is difficult to identify the extent of such reactions and such reactions cannot be avoided in the reactive extrusion process.

Table 1: Phosphorus content of PA6 samples

\begin{tabular}{|c|c|c|c|c|c|c|}
\hline Sample name & $\begin{array}{l}\text { Theoretical } \\
\text { [wt } \%]\end{array}$ & $\begin{array}{l}\text { Actual } \\
{[\mathrm{wt} \%]}\end{array}$ & $\begin{array}{l}\mathrm{CHCl}_{3} \text { Extraction } \\
@ 100^{\circ} \mathrm{C}, 1 \mathrm{~h} \\
\text { [wt } \% \text { (Retention \%)] }\end{array}$ & $\begin{array}{l}\mathrm{CHCl}_{3} \text { Extraction } \\
@ 100^{\circ} \mathrm{C}, 16 \mathrm{~h} \\
{[\mathrm{wt} \%(\text { Retention \%)] }}\end{array}$ & $\begin{array}{l}\mathrm{H}_{2} \mathrm{O} \text { Extraction } \\
@ 60^{\circ} \mathrm{C}, 16 \mathrm{~h} \\
{[\mathrm{wt} \%(\text { Retention \%)] }}\end{array}$ & $\begin{array}{l}\mathrm{H}_{2} \mathrm{O} \text { Extraction } \\
@ 100^{\circ} \mathrm{C}, 16 \mathrm{~h} \\
\text { [wt } \% \text { (Retention \%)] }\end{array}$ \\
\hline $\begin{array}{l}\text { PA6/DV/PIP } \\
\text { Kneading }\end{array}$ & 0.82 & 0.74 & $0.43(58)$ & - & - & - \\
\hline $\begin{array}{l}\text { PA6/DV/PIP } \\
\text { Compound }\end{array}$ & 0.82 & 0.73 & $0.43(59)$ & $0.41(56)$ & $0.62(85)$ & $0.53(72)$ \\
\hline $\begin{array}{l}\text { PA6/DV/PIP } \\
\text { Fiber }\end{array}$ & 0.82 & 0.73 & $0.54(74)$ & $0.51(70)$ & $0.64(87)$ & $0.57(78)$ \\
\hline
\end{tabular}

DV:DVPPO, PIP: Piperazine

\section{Compounding and Fiber Spinning}

Encouraged by the kneading trials, reactive extrusion of DVPPO and pipearzine were performed to obtain larger amount of PA6 compound. Approximately $2780 \mathrm{~g}$ of PA6 was premixed with $150 \mathrm{~g}$ of DVPPO and $72.6 \mathrm{~g}$ piperazine and extruded in a twin-screw extruder to 
obtain approximately $3 \mathrm{~kg}$ of PA6 compound. In order to ensure a good mixing of the additives with the polymer melt, the extrusion temperature was increased by approx. $20{ }^{\circ} \mathrm{C} \mathrm{com-}$ pared to that used in the kneading experiments. To prevent early melting of DVPPO in extrusion, which can clog the feeding hopper, additional cooling was applied at the inlet of the feeding hopper. Unlike in case of kneading experiment, the color of the polymer remained unchanged which rules out any oxidative decomposition of PA6. This is due to the closed system or inert conditions existing in case of an extruder which avoids any oxygen access to the polymer melt.

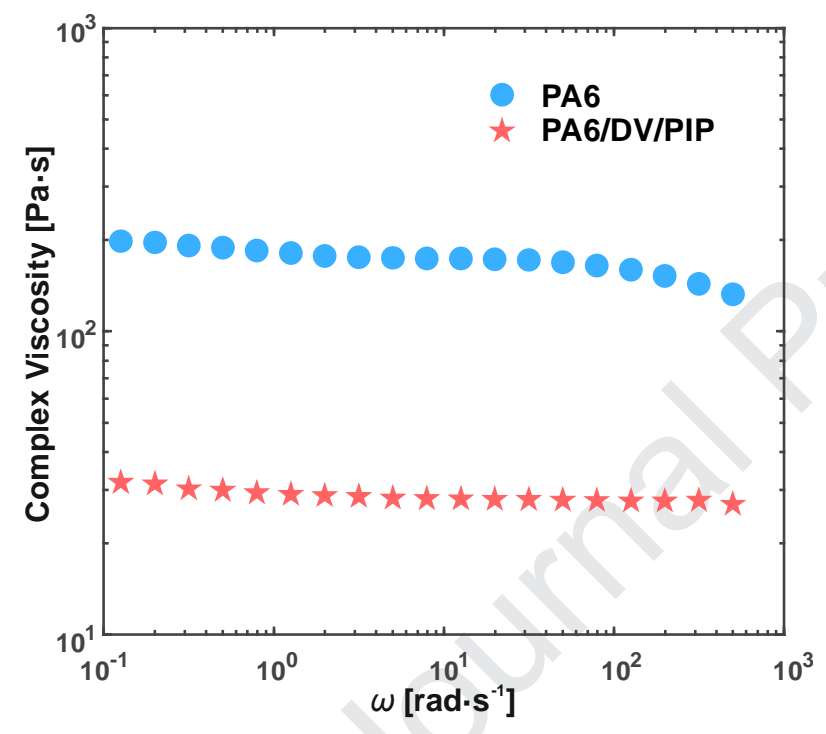

DV:DVPPO, PIP: Piperazine

Figure 1: Rheological behavior of PA6 compounds.

For fiber melt spinning, the polymer compound must withstand processing temperature and shear strain with minimal thermal degradation, have sufficiently high molecular weight and thus enough melt-strength to prevent filament break under drawdown strain, and show high uniformity to prevent fluctuations and blockage in processing. The PA6/DVPPO/Piperazine compound could be melt-spun into fibers however, the extruder pressure went down from 65 bar (virgin PA6) to 13 bar (compound), suggesting a strong lubricating effect of the Michael addition products present in the compound. To further understand the melt behavior of the 
PA6 compound, rheological experiments were performed. As shown in Figure 1, the extruded PA6/DVPPO/Piperazine compound has a lower melt viscosity than PA6 by one order of magnitude. This effect can be ascribed to lubricating action of the reaction products formed from Michael addition of DVPPO and piperazine. A similar lubricating effect was observed for polyester containing a phosphorus flame retardant additive.[46] Thus, one can carry out melt spinning of thermoplastic polymers at lower temperatures, which reduces subsequent thermomechanical degradation processes. It is pointed out here that no attempts to optimize the melt spinning conditions for the PA6 compounds were done. Such lubrication effect of the additives can be overcome by reducing the extrusion temperature during spinning and use of high viscosity (high MW) carrier polymers.

\section{Properties of PA6 compound and Fibers}

The P content (wt.\%) of the PA6 compound and PA6 fibers before and after extraction from chloroform and from water were evaluated in detail. Longer extraction time of $16 \mathrm{~h}$ in chloroform and water was also followed to estimate long-term leaching behavior of the PA6 compound and fiber. Similar to the observation in the preliminary kneading experiments the majority of phosphorus is retained in the PA6 compound and fibers after the extraction indicating formation of phosphine oxide macromolecules. Longer extraction time $(16 \mathrm{~h})$ resulted in slightly lower phosphorus retention compared to shorter extraction time $(1 \mathrm{~h})$. Lower phosphorus retention was observed in case of chloroform extraction compared to water extraction, which may be due to a higher swelling behavior of PA6 in chlorinated solvents compared to in water.[47] Realistically in a real use, it is more likely that a PA6 fiber or its product is exposed to aqueous environment than an organic solvent like chloroform. Relative to PA6 compound the PA6 fiber showed higher P retention (wt.\%) in both solvent extractions which may be due to an increased chance of reaction of Michael adducts (starting raw materials and subsequent reaction products) and further entanglements of Michael addition products during the 
second thermal process (i.e. fiber spinning). It is pointed out here that no leaching of phosphorus species was observed when extraction was performed with water at room temperature ( for 1 to $16 \mathrm{~h}$ duration) for PA6 compound and fibers.

Table 2. Thermal properties of PA6 Samples

\begin{tabular}{llllll}
\hline Sample name & $\begin{array}{l}\mathrm{T}_{\mathrm{d} 5 \%} / \mathrm{N}_{2} \\
{\left[{ }^{\circ} \mathrm{C}\right]}\end{array}$ & $\begin{array}{l}\mathrm{T}_{\mathrm{dmain}} / \mathrm{N}_{2} \\
{\left[{ }^{\circ} \mathrm{C}\right]}\end{array}$ & $\begin{array}{l}\text { Residual Mass } \\
\text { wt.\% }\left(800{ }^{\circ} \mathrm{C}\right)\end{array}$ & $\begin{array}{l}\text { Melting } \\
\text { Point } \\
{\left[{ }^{\circ} \mathrm{C}\right]}\end{array}$ & $\begin{array}{l}\text { Crystallization Point } \\
{\left[{ }^{\circ} \mathrm{C}\right]}\end{array}$ \\
\hline Virgin PA6 & 388 & 453 & 0.2 & 222 & 195 \\
PA6/DV/PIP compound & 347 & 426 & 2.9 & 220 & 180 \\
$\begin{array}{l}\text { PA6 fiber } \\
\text { PA6/DV/PIP fiber }\end{array}$ & 374 & 454 & 3.2 & 221 & 176 \\
& 349 & 423 & 1.8 & 220 & 179 \\
\hline
\end{tabular}

$\mathrm{T}_{\mathrm{dmain}}$ : Temperature at maximum decomposition rate

The thermal properties of PA6 samples were analyzed using TGA and DSC and are summarized in Table 2. The TGA analysis of a polymer containing flame retardant additive provides; useful information regarding the degradation of the polymer during its processing, helps determine possible processing temperature and information regarding possible interaction of flame retardant additives with the polymer. Compared to the virgin PA6 the processed PA6 with and without phosphine oxide products had slightly lower melting point, significantly lower crystallization point, lower decomposition temperature. PA6/DVPPO/Piperazine compound had significantly lower $\mathrm{T}_{\mathrm{d} 5 \%}$ and $\mathrm{T}_{\mathrm{dmain}}$ which is possibly due to the chemical interaction of phosphine oxide moieties with the polymer at elevated temperatures. Though the $\mathrm{T}_{\mathrm{d} 5 \%}$ of the PA6/DVPPO/Piperazine compound $\left(347^{\circ} \mathrm{C}\right)$ is lower than the virgin PA6 $\left(388^{\circ} \mathrm{C}\right)$, it is still higher than the normal processing temperature of PA6 $\left(250-300{ }^{\circ} \mathrm{C}\right)$. Lower $\mathrm{T}_{\mathrm{dmain}}$ of the PA6/DVPPO/Piperazine compound and PA6/DVPPO/Piperazine fiber compared to virgin PA6 is a clear indication of condensed phase interaction of phosphine oxide macromolecules with the PA6. However, the $\%$ residual mass $\left(800{ }^{\circ} \mathrm{C}\right.$ ) of modified PA6 samples were simi- 
lar to the PA6 without any additive, indicating limited char forming capabilities of phosphine oxide moieties.

The tensile properties of the PA6 fibers were measured to study the influence of incorporation of phosphine oxide moieties in PA6 and the results are summarized in Table 3. It can be seen from the Table 3 that for the PA6/DVPPO/Piperazine fiber the ultimate tensile stress is lower which could be an influence of the phosphine oxide moieties formed from Michael addition reaction. In contrast, the Young's modulus of the PA6/DVPPO/Piperazine fiber is higher than that of the virgin PA6 fiber. GPC analyses of the PA6 fibers were performed to estimate the weight average molecular weights (Mw) of the PA6 samples. It can be seen from Table 3 that the Mw of the PA6 samples are very similar and are not influenced by the processing, which excludes any severe catalyzed degradation of PA6 at elevated temperatures. The differences in tensile properties of the PA6/DVPPO/Piperazine fiber could be due to possible physical interactions, such as hydrogen-bonding, induced by phosphine oxide moieties.[48] It has been shown that such interactions with additives can lead to conformational locking schemes in similar materials, which could alter the mechanical properties of the polymers.[49] Any further investigation of the difference in mechanical properties of PA6 fibers is beyond the scope of this work and will be addressed in a future publication.

Table 3: Tensile strength and Molecular weights of PA6 fibers

\begin{tabular}{|c|c|c|c|c|c|c|c|}
\hline Sample name & $\begin{array}{l}\text { Linear mass } \\
\text { density } \\
(\text { tex }=\mathrm{mg} / \mathrm{m})\end{array}$ & $\begin{array}{l}\text { Ultimate } \\
\text { stress } \\
(\mathrm{cN} / \mathrm{tex})\end{array}$ & tensile & $\begin{array}{l}\text { Ultimate tensile } \\
\text { stress } \\
(\mathrm{MPa})\end{array}$ & $\begin{array}{l}\text { Ultimate tensile } \\
\text { strain }(\%)\end{array}$ & $\begin{array}{l}\text { Young's } \\
\text { Modulus } \\
(\mathrm{GPa})\end{array}$ & $\begin{array}{l}\text { Molecular weight } \\
\text { Mw ( Daltons) }\end{array}$ \\
\hline PA6-Fiber & 2.81 & $59.7 \pm 1.4$ & & $680 \pm 16$ & $52.0 \pm 2.4$ & $2.62 \pm 0.10$ & 17911 \\
\hline PA6/DV/PIP-Fiber & 2.89 & $41.3 \pm 2.0$ & & $471 \pm 23$ & $39.7 \pm 4.7$ & $3.90 \pm 0.25$ & 17056 \\
\hline
\end{tabular}

DV: DVPPO; PIP: Piperazine; Mw: Weight average molecular weight 
To further evaluate the fire performance of the modified PA6, small-scale fire tests were performed. As there exists no standard fire test for fibers, the virgin PA6 and PA6/DVPPO/Piperazine compound were converted into plates of $1 \mathrm{~mm}$ thickness using a hot press at $250{ }^{\circ} \mathrm{C}$. The plates were then subjected to LOI measurements and vertical burning tests (Swiss standard). The results of fire tests are summarized in Table 4. The modified PA6 has higher LOI values and shorter after flame compared to unmodified PA6. Thus, it is clear that the incorporation of phosphine oxide macromolecules via reactive extrusion in PA6 improves its flame retardancy.

It is likely that the decomposition products of phosphine oxide moieties are active predominantly in the gas phase. DIP-MS data of PA6 and PA6/DV/PIP compound was performed and the results are summarized in supplementary information S4B. The formation of gas phase active phosphorus species such as $\mathrm{PO}^{*}(\mathrm{~m} / \mathrm{z} 47)$ and $\mathrm{CH}_{2}(\mathrm{POH}) \mathrm{CH}_{2}(\mathrm{~m} / \mathrm{z} 104)$ was identified during the thermal decomposition of the PA6/DV/PIP compound. Such phosphorus species can act in the gas phase flame inhibition process. In addition, as no improvement of char formation for modified PA6/DV/PIP compound in TGA data (table 2) was observed. Thus, this supports the hypothesis of absence of condensed phase action of the phosphine oxide moieties.

Table 4: Summary of small-scale fire tests

\begin{tabular}{llll}
\hline & \multicolumn{3}{l}{ BKZ-VB } \\
\cline { 3 - 4 } Sample name & $\begin{array}{l}\text { LOI } \\
{[\text { vol \%] }}\end{array}$ & $\begin{array}{l}\text { Damaged length } \\
{[\mathrm{cm}]}\end{array}$ & $\begin{array}{l}\text { Afterflame } \\
{[\mathrm{s}]}\end{array}$ \\
\hline Virgin PA6 & 25.6 & 4.80 & 18 \\
\hline PA6/DV/PIP compound & 30.2 & 2.27 & 1 \\
\hline DV: DVPPO; PIP: Piperazine; & & &
\end{tabular}


The elemental analysis of the modified PA6 (PA6/DV/PIP compound and PA6/DVPPO/Piperazine fiber) after extraction showed P (wt. \%) retention between 60-85\% indicating formation of phosphine oxide macromolecules. To gain further evidence regarding their formation we performed NMR analysis of the extruded PA6/DVPPO/Piperazine fiber in a deuterated hexafluorisopropanol (HFIP- $\left.\mathrm{d}_{2}\right)$.

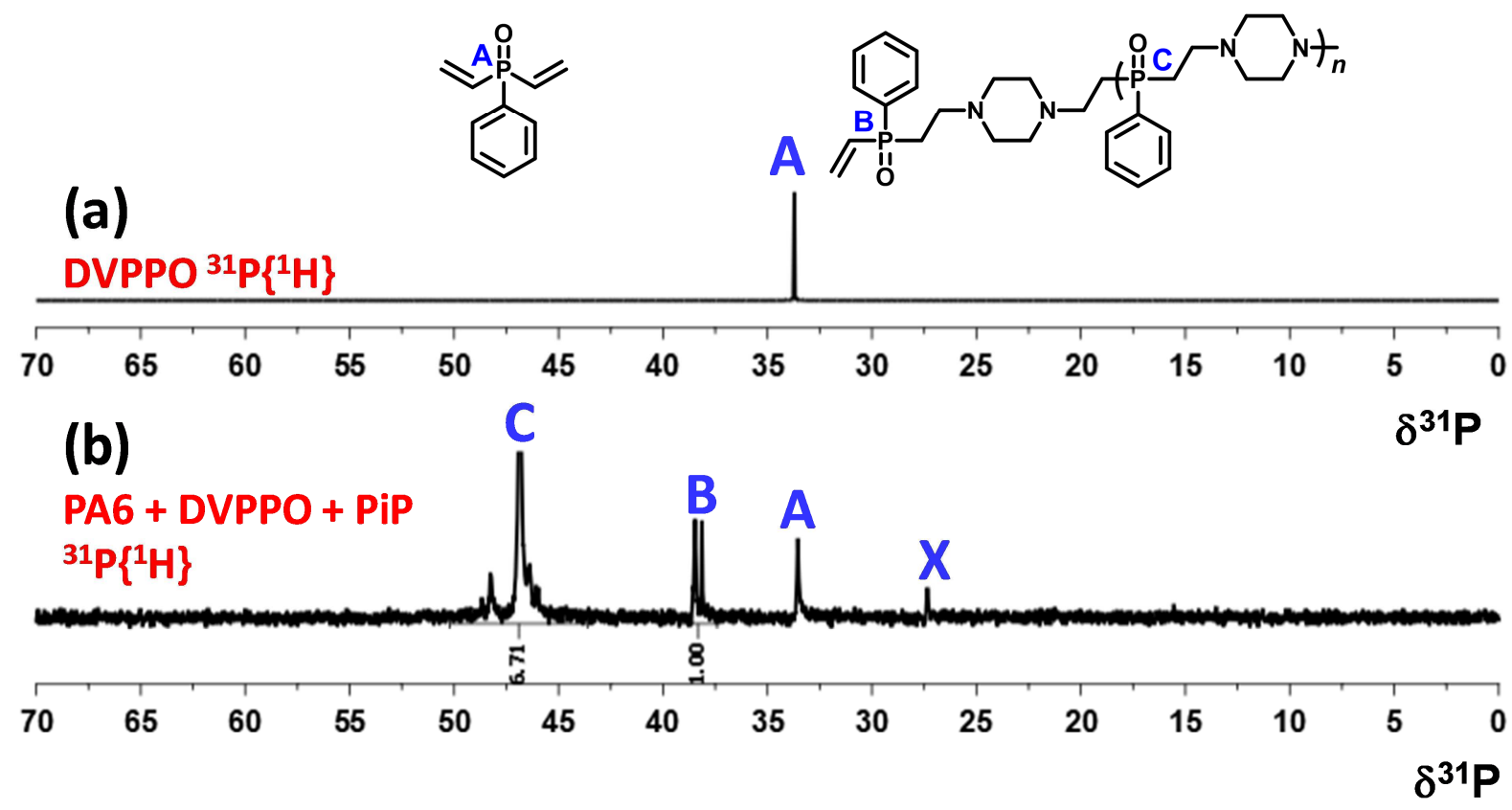

Figure 2. NMR data of modified PA6 /DVPPO/Piperazine

a) ${ }^{31} \mathrm{P}\left\{{ }^{1} \mathrm{H}\right\}$ spectra of DVPPO b) ${ }^{31} \mathrm{P}\left\{{ }^{1} \mathrm{H}\right\}$ spectra of PA6/DV/PIP fiber (HFIP- $\mathrm{d}_{2}$ ).

Figure 2 shows the ${ }^{31} \mathrm{P}$ spectra of DVPPO (2a) and PA6/DV/PIP fiber (2b). For spectra corresponding to ${ }^{31} \mathrm{P}$ of PA6/DVPPO/Piperazine fiber (2b), phosphorus peak at $33.6 \mathrm{ppm}$ can be assigned to unreacted DVPPO (P-A). This presence of unreacted DVPPO correlates well with the loss of P (wt. \%) content of the PA6 samples in the extraction experiments (Table 1). Any unreacted DVPPO will leach out in the extraction experiments. The resonance at $38.5-38.1$ ppm corresponds to phosphorus atoms connected to terminal vinyl groups (P-B) and additional peaks at 48.3-46.9 ppm can be assigned to phosphorus atoms present in the backbone of phosphine oxide macromolecules (P-C). A small peak at $28 \mathrm{ppm}$ could not be assigned at this stage. It is to be noted here that the ratio of phosphorus atoms P-C:P-B was found out to be 


\section{Journal Pre-proof}

7:1 thus indicating formation of phosphine oxide macromolecules. To confirm these assignments of the phosphorus peaks for PA6 samples, we performed model kinetic Michael addition studies involving DVPPO and piperazine in microwave reactor at $100{ }^{\circ} \mathrm{C}$ without the use of any solvent. Though the reaction environment for DVPPO and peperazine in an extruder with PA6 matrix is quite different to the microwave condition, the neat reactions in microwave can be considered as a model experiment and could be similar to that in the extruder. To exclude the formation of other products in a microwave synthesis procedure, Michael addition reaction was also performed in a sealed glass tube on a hot plate. The results of this kinetic study are summarized in Figure $3\left({ }^{31} \mathrm{P}\right.$ spectra) and supplementary information (S5A, ${ }^{1} \mathrm{H}$ spectra and $\mathrm{S} 5 \mathrm{~B},{ }^{31} \mathrm{P}$ spectra). 


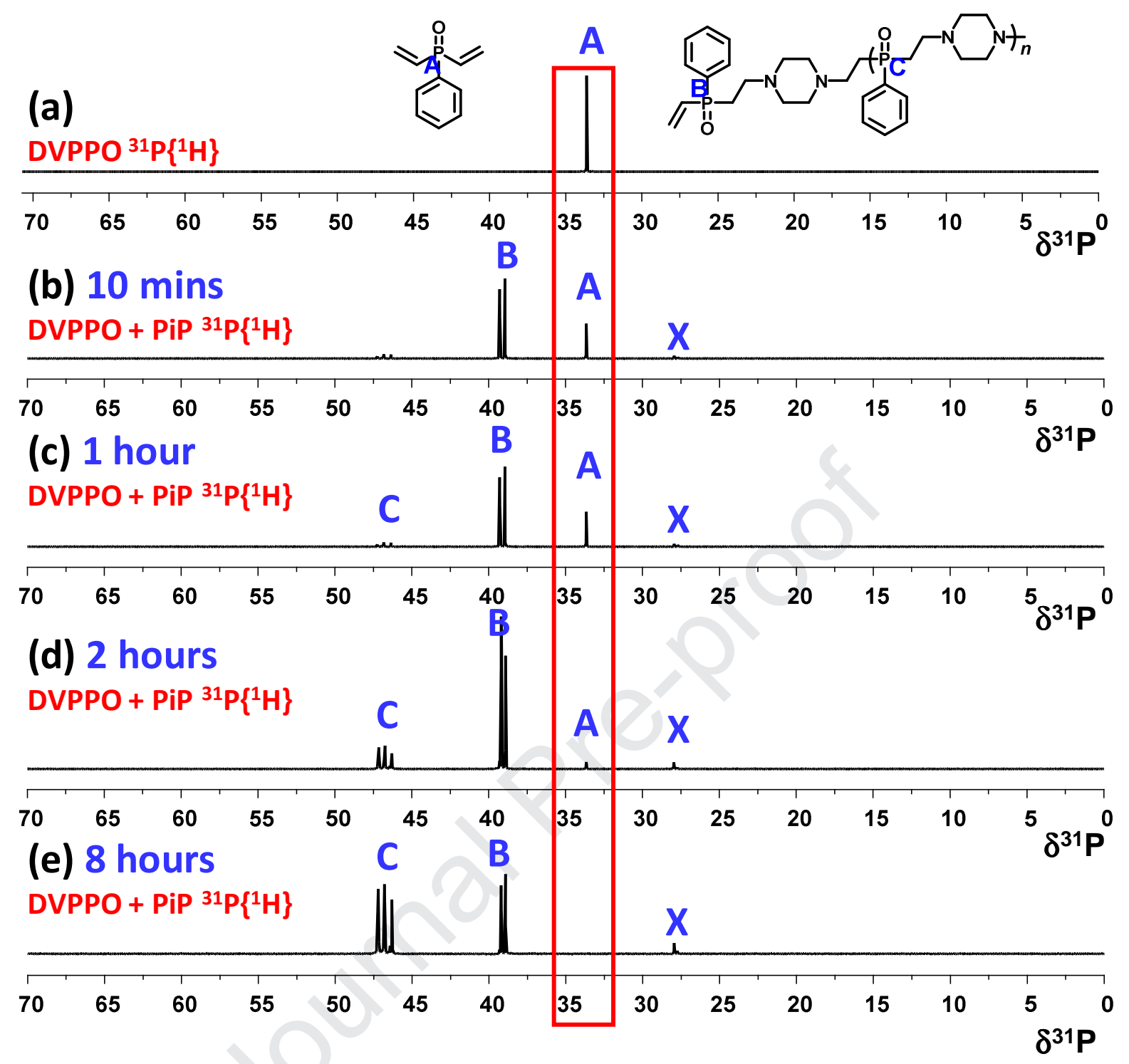

Figure 3. Michael addition kinetic study

a) ${ }^{31} \mathrm{P}\left\{{ }^{1} \mathrm{H}\right\}$ NMR spectrum of DVPPO, b) ${ }^{31} \mathrm{P}\left\{{ }^{1} \mathrm{H}\right\}$ NMR spectrum DVPPO with piperazine after 10 minutes, c) ${ }^{31} \mathrm{P}\left\{{ }^{1} \mathrm{H}\right\}$ NMR spectrum of DVPPO with piperazine after 1 hour, d) ${ }^{31} \mathrm{P}\left\{{ }^{1} \mathrm{H}\right\}$ NMR spectrum of DVPPO with piperazine after 2 hours e) ${ }^{31} \mathrm{P}\left\{{ }^{1} \mathrm{H}\right\}$ NMR spectrum of DVPPO with piperazine after 8 hours $\left(\right.$ HFIP- $\left.\mathrm{d}_{2}\right)$.

In these experiments during the first phase of reaction (reaction time 10 minutes-Figure $3 \mathrm{~b}$ and S5A, b) conversion of both monomers to Michael addition products were observed. This was evidenced from the appearance of B peaks (38.5-38.1ppm), C peaks (48.3-46.9) and a small peak $\mathrm{X}$ at $28 \mathrm{ppm}$. Interestingly the same peak is also observed in the ${ }^{31} \mathrm{P}$ NMR spectrum for PA6/DVPPO/Piperazine fiber. This clearly indicates that the phosphorus peak at 28 
ppm may arise from unknown homo-polymerization of DVPPO or with Michael addition reaction products and not from any side reaction with PA6 polymer. With increase in reaction time, the intensity of the peak corresponding to DVPPO decreases and the intensity of peak C and peak $\mathrm{X}$ increases. Compared to peak $\mathrm{C}$ the intensity of peak B initially increases and then decrease with time clearly indicating their relationship. At reaction time of 8 hours all DVPPO was consumed which was confirmed by the disappearance of the phosphorus peak at 33.6 ppm. ${ }^{31} \mathrm{P}$ NMR spectra of microwave generated products and those produced in the reactive extrusion process are very similar to the ones produced in hot plate experiments $\left(\mathrm{S} 5 \mathrm{~B},{ }^{31} \mathrm{P}\right.$ spectra) thus confirming formation of similar reaction products in different conditions. In ${ }^{1} \mathrm{H}$ NMR spectrum (supplementary information S5A), macromolecule bound $\mathrm{P}(\mathrm{O})-\mathrm{CH}_{2}$ group (H- $\alpha 1)$ appeared at 2.46-2.33 ppm which confirms the Michael addition reaction of the adducts. Furthermore, $\mathrm{CH}_{2}$ group $(\mathrm{H}-\beta 1)$ attached to a $\mathrm{CH}_{2}$ carbon $\left(\mathrm{P}(\mathrm{O})-\mathrm{CH}_{2}-\mathrm{CH}_{2}\right)(\delta 3.16-2.97$ ppm) and at $\delta 2.84-2.66$ ppm signal can be assigned to a $\mathrm{CH}_{2}(\mathrm{H}-\mathrm{C})$ group of phosphine oxide macromolecules. Furthermore, the proton signals at $\delta 7.74-7.64$ ppm can be assigned as aromatic $\mathrm{CH}(\mathrm{H}-\mathrm{A})$ and peaks at $6.56-6.27 \mathrm{ppm}$ is assigned to terminal vinyl group $(\mathrm{H}-\alpha+\beta)$. The reduction in intensity of proton (supporting information S5A) corresponding to the vinyl groups, with increase in the reaction time in model experiments correlates well with the reduction of peak corresponding to phosphorus at $33.6 \mathrm{ppm}$ in ${ }^{31} \mathrm{P}$ NMR spectra (Figure 3). As the phosphine oxide macromolecules formed from the Michael addition reaction in model experiments are poorly soluble in common organic solvents, we performed MALDI-TOF analysis and the results are presented in supplementary information S6. It is clear from the supporting information S6 that the Michael addition reaction of the DVPPO and piperazine leads to formation of phosphine oxide based macromolecules whose molecular weight ranges from 265 to $4140 \mathrm{amu}$. Thus, it is likely such macromolecules can also be formed during the reactive extrusion process. The extracts of PA6/DVPPO/Piperazine fibers were also analyzed using UPLC-MS and results are summarized in the supporting information S7. The extract re- 
covered from the fiber is mixture of unreacted piperazine, DVPPO and their Michael addition reaction products, which corroborates the NMR data. Reactive extrusion experiments of DVPPO and piperazine confirms the retention of majority $\mathrm{P}$ (wt. \%) in the PA6 matrix, however to avoid any leaching of phosphorus species from PA6 the reactive extrusion process needs to be optimized. As a precautionary step, unreacted or low molecular weight species can be extracted from fibers in a prewash before they are introduced in the market.

\section{Preliminary in vitro toxicity assessment of DVPPO}

Comprehensive toxicological in vivo studies (in animals) are time consuming, costly and thus inadequate to accompany the early stages of material development. Therefore, we made use of a well-established in vitro platform to assess the safety of DVPPO. Following the ideas of ISO and OECD guidelines the platform is designed to assess potential adverse effects on cell viability in due time and according to the so-called reactive oxygen species (ROS) paradigm. It has been successfully applied in previous studies on flame retardant toxicity $[34,50]$ but also to determine nanomaterial induced adverse effects. [51] Piperazine is a well known compound, is contained in different drugs and considered a rather safe and nontoxic substance "in the usual doses". [52] According to an EU risk assessment report on peperazine "there is no concern for acute toxicity" for humans.[53] Therefore, in this work the toxicological assessment of the relatively unknown molecule DVPPO was the major focus.

A persistent ROS overload in cultured cells can lead to serious damage of biomolecules (as for example lipids, nucleic acids and proteins) and is therefore considered one of the first indicators of cellular stress reactions. Subsequent consequences can be inflammation and cell death ([54] and references therein). Therefore, our screening approach monitored ROS as a first stressor and cell viability/cell death as one of the final, most severe measurable effects in 
two model cell lines: the human lung epithelial cell line A549 and macrophages derived from the monocytic cell line THP-1.

While the positive control Sin-1 induced a 64- and 47-fold increase in ROS production in A549 and THP-1 cells, respectively, DVPPO did not increase the level of ROS beyond background levels measured in the solvent control ("0 $\mu \mathrm{M}$ DVPPO", Figure 4). This held true for concentrations up to $400 \mu \mathrm{M}$, which resemble worst case but still realistic exposure conditions [50]. Furthermore, direct comparison to existing literature on flame retardant toxicity is possible in this particular concentration range $[55,56]$. From these results we can conclude that within the first two hours of treatment DVPPO does not induce a burst release of ROS in the two cell lines. 


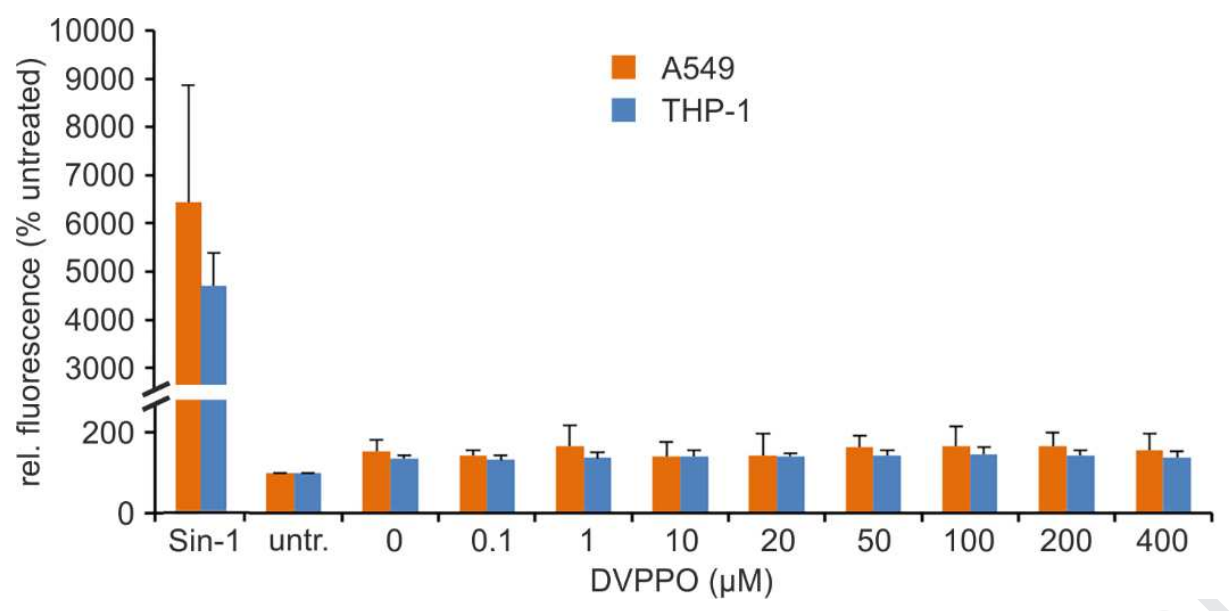

Figure 4: Analysis of ROS production in A549 cells and THP-1 macrophages in the presence of DVPPO. Up to a concentration of $400 \mu \mathrm{M}$ and $2 \mathrm{~h}$ of incubation, DVPPO did not induce the elevation of ROS levels, in neither A549 cells nor THP-1 macrophages. Sin-1 $(50 \mu \mathrm{M})$ served as the positive control. Values are normalized to untreated control samples and represent the mean and corresponding standard deviations of three independent experiments with three technical replicates each.

However, adverse effects manifested at later time points cannot be excluded yet. Therefore, cell viability in response to DVPPO treatment was assessed in A549 cells as well as THP-1 macrophages after 3, 24 and $48 \mathrm{~h}$ of incubation using the MTS assay (Supplementary information S9 B\&D; Figure 5B). Up to a concentration of $400 \mu \mathrm{M}$ and $48 \mathrm{~h}$ of treatment, DVPPO did not affect cell viability of both cell types (Figure 5B). In contrast, the positive control $\mathrm{CdSO}_{4}$ reduced cell viability in both cell types dose dependently (Figure 5A, supplementary information S9 A\&C). 

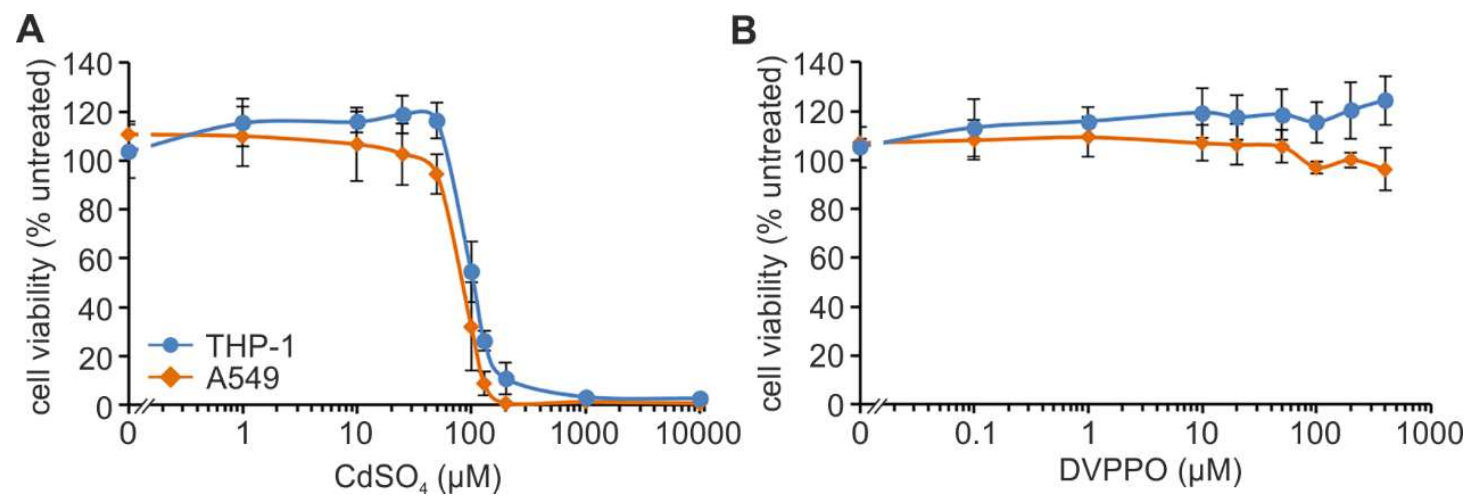

Figure 5: Analysis of cell viability in A549 cells and THP-1 macrophages in the presence of DVPPO. Cell viability is not influenced by DVPPO up to a concentration of $400 \mu \mathrm{M}$ and $48 \mathrm{~h}$ of incubation. A549 cells (black rhombs) as well as THP-1 macrophages (grey circles) were treated for $48 \mathrm{~h}$ with increasing concentrations of DVPPO (B) or $\mathrm{CdSO}_{4}$ (A) as a positive control. Cell viability was measured using the MTS assay. Values are normalized to untreated control samples and represent the mean and corresponding standard deviations of three independent experiments with three technical replicates each. The legend shown in (A) applies to both graphs (A and B).

To rule out a potential sub-lethal impact of DVPPO, DNA strand breaks, as a measure of genotoxicity, and the release of the pro-inflammatory cytokine TNF- $\alpha$ were investigated in THP1 macrophages. DVPPO induced neither DNA strand breaks nor the release of TNF- $\alpha$ (Supplementary information S10 and S11).

Taken together, in two model cell lines, DVPPO did not affect relevant endpoints of acute cytotoxicity in vitro, namely ROS production and cell viability. Furthermore, DNA damage and cytokine release were not affected by DVPPO in THP-1 macrophages. Hence, DVPPO could be considered as a promising, and safe reactive flame retardant precursor. 


\section{Conclusion}

Feasibility of flame retardant functional modification of PA6 via a novel reactive extrusion process was demonstrated in this work. The functional modification of PA6 was performed via Michael addition of DVPPO and piperazine during the melt extrusion of PA6. In situ formation of phosphine oxide based macromolecules (oligomers and low molecular weight polymers) were confirmed via chemical characterization of the modified PA6 and its extract via NMR and UPLC-MS measurements respectively. In situ formation of phosphine oxide base macromolecules in reactive extrusion can be considered a green strategy and its non-leaching behavior positively contributes to its ecological profile. Lubricating influence of phosphine oxide macromolecules during the processing of PA6 was observed which necessitates future optimization possibly with higher molecular weight carrier polymer and working at lower processing temperatures to improve the melt strength. The modified PA6 demonstrated improved fire performance in small-scale tests. Following up on holistic sustainable development of flame retardant materials, the preliminary in vitro toxicity assessment indicates no adverse effects of the relatively unknown DVPPO on acute cytotoxicity. However, additional in vivo studies as well as eco-toxicological aspects have to be performed for a comprehensive assessment of potential health risks. Furthermore, health safety aspects of the final flame retardant product (not only of the new additive) have to be evaluated. This however is beyond the scope of the present study. Future work will also explore the use of other Michael adducts (various amines) and improving the yield of Michael addition reaction during reactive extrusion process to avoid any residual unreacted adducts and leachable low molecular weight products. 


\section{Acknowledgements}

The Authors acknowledge Zürcher Stiftung für Textilforschung (project number 116) for partially funding the project. We further like to acknowledge Mr. Mathias Lienhard for kneading and extrusion trials and Mr. Benno Wüst for melt spinning trials.

\section{References}

[1] Schmitt E. Phosphorus-based flame retardants for thermoplastics. Plastics, Additives and Compounding. 2007;9(3):26-30.

[2] Buczko A, Stelzig T, Bommer L, Rentsch D, Heneczkowski M, Gaan S. Bridged DOPO derivatives as flame retardants for PA6. Polymer Degradation and Stability. 2014;107:158-65.

[3] Butnaru I, Fernández-Ronco M, Czech-Polak J, Heneczkowski M, Bruma M, Gaan S. Effect of Meltable Triazine-DOPO Additive on Rheological, Mechanical, and Flammability Properties of PA6. Polymers. 2015;7(8):1469.

[4] Alperstein D, Kornberg N, Knani D. A study of fire retardant blooming in HIPS by molecular modeling. Polym Adv Technol. 2011;22(10):1446-51.

[5] Osako M, Kim Y-J, Sakai S-i. Leaching of brominated flame retardants in leachate from landfills in Japan. Chemosphere. 2004;57(10):1571-9.

[6] van der Veen I, de Boer J. Phosphorus flame retardants: Properties, production, environmental occurrence, toxicity and analysis. Chemosphere. 2012;88(10):1119-53.

[7] Wei G-L, Li D-Q, Zhuo M-N, Liao Y-S, Xie Z-Y, Guo T-L, et al. Organophosphorus flame retardants and plasticizers: Sources, occurrence, toxicity and human exposure. Environmental Pollution. 2015;196:29-46.

[8] Hahladakis JN, Velis CA, Weber R, Iacovidou E, Purnell P. An overview of chemical additives present in plastics: Migration, release, fate and environmental impact during their use, disposal and recycling. Journal of Hazardous Materials. 2018;344:179-99.

[9] Liu S, Sun G. Radical graft functional modification of cellulose with allyl monomers: Chemistry and structure characterization. Carbohydrate Polymers. 2008;71(4):614-25.

[10] Oliveira FR, Zille A, Souto AP. Dyeing mechanism and optimization of polyamide 6,6 functionalized with double barrier discharge (DBD) plasma in air. Applied Surface Science. 2014;293:177-86.

[11] Beach MW, Hull JW, King BA, Beulich II, Stobby BG, Kram SL, et al. Development of a new class of brominated polymeric flame retardants based on copolymers of styrene and polybutadiene. Polym Degrad Stab. 2017;135:99-110.

[12] Chen L, Ruan C, Yang R, Wang Y-Z. Phosphorus-containing thermotropic liquid crystalline polymers: a class of efficient polymeric flame retardants. Polym Chem. 2014;5(12):3737-49.

[13] Schwarzer M, Korwitz A, Komber H, Häußler L, Dittrich B, Schartel B, et al. Phosphorus-Containing Polymer Flame Retardants for Aliphatic Polyesters. Macromolecular Materials and Engineering. 2018;303(2):1700512.

[14] Taeuber K, Marsico F, Wurm FR, Schartel B. Hyperbranched poly(phosphoester)s as flame retardants for technical and high performance polymers. Polym Chem. 2014;5(24):7042-53.

[15] Battig A, Markwart JC, Wurm FR, Schartel B. Hyperbranched phosphorus flame retardants: multifunctional additives for epoxy resins. Polymer Chemistry. 2019. 
[16] Rakotomalala M, Wagner S, Döring M. Recent Developments in Halogen Free Flame Retardants for Epoxy Resins for Electrical and Electronic Applications. Materials. 2010;3(8):4300-27.

[17] Toldy A, Szolnoki B, Marosi G. Flame retardancy of fibre-reinforced epoxy resin composites for aerospace applications. Polymer Degradation and Stability. 2011;96(3):371-6.

[18] Mohanty AK, Misra M, Drzal LT. Sustainable Bio-Composites from Renewable Resources: Opportunities and Challenges in the Green Materials World. Journal of Polymers and the Environment. 2002;10(1):19-26.

[19] Badrossamay MR, Sun G. A Study on Melt Grafting of N-Halamine Moieties onto Polyethylene and Their Antibacterial Activities. Macromolecules. 2009;42(6):1948-54.

[20] Graebling D. Synthesis of Branched Polypropylene by a Reactive Extrusion Process. Macromolecules. 2002;35(12):4602-10.

[21] Xu M, Yan H, He Q, Wan C, Liu T, Zhao L, et al. Chain extension of polyamide 6 using multifunctional chain extenders and reactive extrusion for melt foaming. European Polymer Journal. 2017;96:210-20.

[22] Chen Y, Liu Y, Wang Q, Yin H, Aelmans N, Kierkels R. Performance of intumescent flame retardant master batch synthesized through twin-screw reactively extruding technology: effect of component ratio. Polym Degrad Stab. 2003;81(2):215-24.

[23] Wang D-Y, Liu Y, Wang Y-Z, Artiles CP, Hull TR, Price D. Fire retardancy of a reactively extruded intumescent flame retardant polyethylene system enhanced by metal chelates. Polym Degrad Stab. 2007;92(8):1592-8.

[24] Wang Q, Chen Y, Liu Y, Yin H, Aelmans N, Kierkels R. Performance of an intumescent-flameretardant master batch synthesized by twin-screw reactive extrusion: effect of the polypropylene carrier resin. Polym Int. 2004;53(4):439-48.

[25] Bourbigot S, Fontaine G, Gallos A, Bellayer S. Reactive extrusion of PLA and of PLA/carbon nanotubes nanocomposite: processing, characterization and flame retardancy. Polymers for Advanced Technologies. 2011;22(1):30-7.

[26] Gallos A, Fontaine G, Bourbigot S. Reactive extrusion of intumescent stereocomplexed poly-L,Dlactide: characterization and reaction to fire. Polym Adv Technol. 2013;24(1):130-3.

[27] Cheng $X$, Jiang D. Flame retardant polyolefin-type resin and preparation method as well as optic fiber cable using the same; WO2018080773A1. Corning Incorporated, USA . 2018. p. 23pp.

[28] Huang G, Li X. Applications of Michael Addition Reaction in Organic Synthesis. Curr Org Synth. 2017;14(4):568-71.

[29] Brahmachari G, Gorai D. Michael addition reaction: applications in total synthesis of bioactive natural products. Alpha Science International Ltd.; 2009. p. 782-804.

[30] Sun Y, Liu H, Cheng L, Zhu S, Cai C, Yang T, et al. Thiol Michael addition reaction: a facile tool for introducing peptides into polymer-based gene delivery systems. Polym Int. 2018;67(1):25-31.

[31] Mather BD, Viswanathan K, Miller KM, Long TE. Michael addition reactions in macromolecular design for emerging technologies. Progress in Polymer Science. 2006;31(5):487-531.

[32] Liu $M$, Yin $H$, Chen $X$, Yang J, Liang $Y$, Zhang J, et al. Preliminary ecotoxicity hazard evaluation of DOPO-HQ as a potential alternative to halogenated flame retardants. Chemosphere. 2018;193:126-33.

[33] Waaijers SL, Hartmann J, Soeter AM, Helmus R, Kools SAE, de Voogt $P$, et al. Toxicity of new generation flame retardants to Daphnia magna. Science of The Total Environment. 2013;463-464:10428.

[34] Salmeia KA, Gooneie A, Simonetti P, Nazir R, Kaiser J-P, Rippl A, et al. Comprehensive study on flame retardant polyesters from phosphorus additives. Polymer Degradation and Stability. 2018;155:22-34.

[35] Hirsch C, Striegl B, Mathes S, Adlhart C, Edelmann M, Bono E, et al. Multiparameter toxicity assessment of novel DOPO-derived organophosphorus flame retardants. Archives of Toxicology. 2017;91(1):407-25. 
[36] EMPA's environmentally friendly EDA-DOPO flame retardant poised for market entry. Additives for Polymers. 2017;2017(11):1-2.

[37] Jankowski OD, Palmer JT, Honigberg L. Preparation of arylaminoimidazoisoquinolinones as inhibitors of Bruton's tyrosine kinase (Btk) for treatment of B-cell proliferative disorders. Pharmacyclics, Inc., USA . 2007. p. 127 pp.

[38] Hufenus R, Reifler FA, Maniura-Weber K, Spierings A, Zinn M. Biodegradable Bicomponent Fibers from Renewable Sources: Melt-Spinning of Poly(lactic acid) and Poly[(3-hydroxybutyrate)-co-(3hydroxyvalerate)]. Macromolecular Materials and Engineering. 2012;297(1):75-84.

[39] Liang S, Neisius $M$, Mispreuve $H$, Naescher $R$, Gaan S. Flame retardancy and thermal decomposition of flexible polyurethane foams: Structural influence of organophosphorus compounds. Polymer Degradation and Stability. 2012;97(11):2428-40.

[40] Roesslein M, Hirsch C, Kaiser J-P, Krug HF, Wick P. Comparability of in vitro tests for bioactive nanoparticles: a common assay to detect reactive oxygen species as an example. Int J Mol Sci. 2013;14(12):24320-37.

[41] Varnes JG, Gero T, Huang S, Diebold RB, Ogoe C, Grover PT, et al. Towards the next generation of dual Bcl-2/Bcl-xL inhibitors. Bioorganic \& Medicinal Chemistry Letters. 2014;24(14):3026-33.

[42] Polyethylene Modification by Reactive Extrusion. Handbook of Industrial Polyethylene and Technology. p. 715-49.

[43] Liu K, Li Y, Tao L, Xiao R. Preparation and characterization of polyamide 6 fibre based on a phosphorus-containing flame retardant. RSC Advances. 2018;8(17):9261-71.

[44] Welch FJ. Polymerization of vinyl phosphoryl compounds, US3519607A. Union Carbide Corp. . 1970. p. 6 pp.

[45] Close J, Grimm J, Heidebrecht RW, Jr., Kattar S, Miller TA, Otte KM, et al. Preparation of phosphorus derivatives as histone deacetylase inhibitors; WO2008010985A2. Merck \& Co., Inc., USA . 2008. p. 207 pp.

[46] Gooneie A, Simonetti P, Salmeia KA, Gaan S, Hufenus R, Heuberger MP. Enhanced PET processing with organophosphorus additive: Flame retardant products with added-value for recycling. Polymer Degradation and Stability. 2019;160:218-28.

[47] Haga T, Ishibashi H. Interactions between nylon 6 fiber and organic solvents. Sen'i Gakkaishi. 1973;29(2):72-9.

[48] Jackson NE, Savoie BM, Kohlstedt KL, Olvera de la Cruz M, Schatz GC, Chen LX, et al. Controlling Conformations of Conjugated Polymers and Small Molecules: The Role of Nonbonding Interactions. Journal of the American Chemical Society. 2013;135(28):10475-83.

[49] Yount WC, Loveless DM, Craig SL. Small-Molecule Dynamics and Mechanisms Underlying the Macroscopic Mechanical Properties of Coordinatively Cross-Linked Polymer Networks. Journal of the American Chemical Society. 2005;127(41):14488-96.

[50] Hirsch C, Striegl B, Mathes S, Adlhart C, Edelmann M, Bono E, et al. Multiparameter toxicity assessment of novel DOPO-derived organophosphorus flame retardants. Arch Toxicol. 2017;91(1):40725.

[51] Bachmatiuk A, Mendes RG, Hirsch C, Jahne C, Lohe MR, Grothe J, et al. Few-layer graphene shells and nonmagnetic encapsulates: a versatile and nontoxic carbon nanomaterial. ACS Nano. 2013;7(12):10552-62.

[52] Sethi AS, Jain AM, Chawla V. Piperazine toxicity. The Indian Journal of Pediatrics. 1968;35(5):237-8.

[53] Commission E. European Union Risk Assessment Report - piperazine. In: Centre JR, editor. Sweden2005.

[54] Roesslein M, Hirsch C, Kaiser JP, Krug HF, Wick P. Comparability of in vitro tests for bioactive nanoparticles: a common assay to detect reactive oxygen species as an example. Int J Mol Sci. 2013;14(12):24320-37. 
[55] Hendriks HS, Meijer M, Muilwijk $M$, van den Berg $M$, Westerink RHS. A comparison of the in vitro cyto- and neurotoxicity of brominated and halogen-free flame retardants: prioritization in search for safe(r) alternatives. Archives of Toxicology. 2014;88(4):857-69.

[56] Ta N, Li CN, Fang YJ, Liu HL, Lin BC, Jin H, et al. Toxicity of TDCPP and TCEP on PC12 cell: Changes in CAMKII, GAP43, tubulin and NF-H gene and protein levels. Toxicol Lett. 2014;227(3):164-71. 
The authors declare no conflict of interest.

On behalf of all authors.

\section{Dr. Sabyasachi Gaan}

Group Leader (Additives \& Chemistry)

Advanced Fibres

Empa

Swiss Federal Laboratories for Materials Science and Technology

Lerchenfeldstrasse 5

9014 St. Gallen

Switzerland

Tel +41587657611

Fax +41587657862

sabyasachi.gaan@empa.ch

www.empa.ch 